\title{
茶園土堷の腐植に関寸る研究 (第 1 報)*
}

\section{腐植酸のメトキシル基含量と示差吸光曲線について}

\author{
農林省茶業試験場 河 合 惣吾・池ケ谷賢次郎
}

\section{Studies on Humus of Tea Soil (Part 1)}

\section{On Methoxyl Content and Difference Spectrum of Humic Acid}

\section{By Sôgo KawaI and Kenjirô IKEgaya}

\section{1 はしがき}

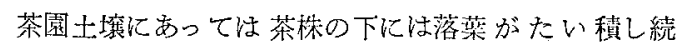
け，う衫閪には多量の敷草が投入されている。茶園土㙋

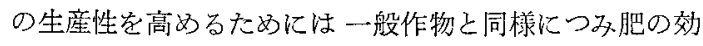
果が大きい。乙かし，腐植の本質的な研究は数多くなさ 、れているにもかかからさ”，生産性との関連については不 明な点が多い。乙れ注腐植の複雑さから，その形態分別 法に決定的なものがないためである当と考光られる。した がって, 茶園土翼の腐植の研究学行なうに当たり，パノ マレバ氏法, 弘法, 大羽によるSIMON の修正法および 腐植酸の示差吸光曲線などにより，生産性安異に卞る牧
之原台地の 3 土墥統について検討を加えた結果，示差吸 光曲線に夕ら呒る腐植酸の性質が 土壤の種類によって異 なり，乙かも腐植化度莸明りょうに示卞ととが認められ たので, 各種茶園土境の腐植酸および落粗類似物買につ いて示差吸光曲線を求め, これと小坂・本腘によるメト キシル基含量とを比較したところ，これらの結果が生産 性との関連のみならず，土潩分類への态用にも期待され たので，第 1 報としてとりまとめ発表することにした。

\section{2 実 験 方 法}

表 1 亿示すごとき一般化学的性質宗す土境を $0.5 \mathrm{~mm}$ のふるいを通過するように摩砕し実験材料とした。

表 1 供試土境の一般化学的性質

\begin{tabular}{|c|c|c|c|c|c|c|c|c|c|c|c|c|}
\hline \multirow{2}{*}{\multicolumn{2}{|c|}{ 土袞名 }} & \multicolumn{2}{|c|}{$\mathrm{pH}$} & \multirow{2}{*}{\begin{tabular}{|c|} 
置換酸度 \\
$y_{1}$
\end{tabular}} & \multirow{2}{*}{ 全窒素 } & \multirow{2}{*}{ 全炭素 } & \multirow{2}{*}{$\mathrm{C} / \mathrm{N}$} & \multirow{2}{*}{ 腐 植 } & \multirow{2}{*}{ 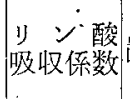 } & \multirow{2}{*}{ 置換容最 } & \multirow{2}{*}{$\mid \begin{array}{r}\mathrm{CEC} \text { 公配 } \\
\mathrm{pH} 7.0 / \\
\mathrm{pH} 5.0\end{array}$} & \multirow{2}{*}{$\begin{array}{l}\text { 石 灰 } \\
\text { 飽和度 }\end{array}$} \\
\hline & & $\mathrm{H}_{2} \mathrm{O}$ & $\mathrm{KCl}$ & & & & & & & & & \\
\hline 牧之 & 1 & $\cdot 5.5$ & 4.5 & 5.4 & $\begin{array}{c}\% \\
0.270\end{array}$ & 2.99 & 11.1 & $5.15^{\circ}$ & 1448 & $\begin{array}{c}\text { me } \\
19.6\end{array}$ & $100 / 94.7$ & 35.1 \\
\hline 牧之 & 2 & 4.4 & 4.1 & 17.5 & 0.320 & 3.75 & 11.7 & 6.46 & 1564 & 22.2 & $100 / 85.6$ & 18.1 \\
\hline 牧之 & & 4.5 & 4.1 & 19.2 & 0.550 & 7.67 & 13.9 & 13.22 & 2048 & 38.5 & $100 / 38.6$ & 4.8 \\
\hline 牧光 & & 5.2 & 4.5 & 15.4 & 0.285 & 10.92 & 34.8 & 18.83 & 3074 & 43.3 & $100 / 35.5$ & 5.0 \\
\hline$\equiv$ & 重 & 4.5 & 3.9 & 19.6 & 0.085 & 1.01 & 11.9 & 1.74 & 728 & 7.8 & $100 / 52.6$ & 10.1 \\
\hline 京 & 都 & 4.5 & 3.9 & 17.4 & 0.147 & 1.53 & 10.4 & 2.64 & 645 & $\cdot 8.6$ & $100 / 84.9$ & 13.5 \\
\hline 富 & \pm & 5.9 & 4.8 & 赤 変 & 0.592 & 10.30 & 17.4 & 17.76 & 3109 & 35.7 & $100^{\prime} 50.4$ & 56.6 \\
\hline 枕 & 崎 & 5.0 & 4.8 & 0.4 & 0.377 & 9.37 & 24.8 & 16.15 & 3535 & 23.3 & $100 / 18.0$ & 11.8 \\
\hline 埼 & 玉 & 5.3 & 4.4 & 2.2 & 0.542 & 8.48 & 16.2 & 14.62 & 2691 & 33.1 & $100^{\prime} 51.0$ & 25.3 \\
\hline
\end{tabular}

\section{1 弘法・大羽による SIMON の修正法}

$0.5 \%$ 水酸化ナトリウム， $0.5 \%$ フッ化ナトリウムある いは $0.1 M$ ピロリン酸ナトリウムなどにより腐植を浸 出し, これら各浸出液ごとに腐植の形態を調べるが, こ れら浸出液間に注一定の関係がなく，わ方国の上うな土 塨の場合には，現在のところ $0.5 \%$ 水酸化ナトリウムに
より浸出される腐植について検討するのがよいと考党ら れているので, その形態を調べた。

乾土 10 20g に相当する未風乾土また㳊風乾細土（本 実験の場合は $0.5 \mathrm{~mm}$ のふるい老通した風乾細土）に対 して，その炭素含量の約 300 倍となるように， $0.5 \%$ 水 酸化ナトリウム溶液を加光, 沸騰している湯浴中にとき

* 茶業技術研究 No. 29，39４7（1964）より転載 
ぞき振とうしながら30分閒加熱し, 冷後, $10,000 \mathrm{rpm}$

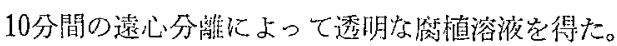

浸出された腐植は腐植酸とフルボ酸とに分別し, 両者 をそれぞれ酸化滴定によって定量する。すな⿰ち，腐植 浸出液の適量をビーカーにとり，その $100 \mathrm{cc}$ 亿刘し $1 \mathrm{cc}$ の割合汇濃硫酸を加えて生ずる沈殿 (腐㥀酸) を還心分 離（4000 rpm 15分）し，1：10の希硫酸で洗液が注とえ ど無色となるまで洗浄遠心分雍する。非沈殿部打よび洗 液合してフルボ酸部とする。しかし，洗液があまり多 くならないよう注意し，わずかに清色する程度になった ら洗浄液はすててもよい。

腐植酸は $1 \%$ 水酸化ナトリウムに溶解させ，水を加光 て一定量にする。このさい腐植の浱度は分光光度計によ って波長 $600 \mathrm{~m} \mu$ で測定した場合の吸光度が 0.1 0.4 程 度であることが望ましく，また，水酸化ナトリウムの漕 度は 0.1 \%となるようにする。

[酸化滴定〕

必要に応じて適当に希釈した腐植浸出液，腐植酸溶液 およびフルボ酸溶液の一定量を $200 \mathrm{cc}$ の三角フラスコに とり，0.1 N の過マンガン酸カリウム $25 \mathrm{cc} ， 4 N$ の硫酸

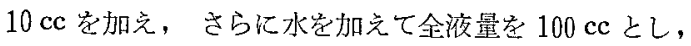
はげしく沸茜している湯浴中に正確に15分間浸清し，た 犬゙ちにやや過剩の $0.1 N$ シニ酸安加えて脱色した後, $0.1 N$ 過マンガン酸カリウムで通滴定する。これより㛚 植抽出液, 腐植酸溶液およびフルボ酸溶液 $30 \mathrm{cc}$ あたり の $0.1 N$ 過マンガン酸カリウム消䨘量を算出する。

注 1 . 吸光度の測定に用いた溶液, つまり希釈した 場合には,その液について酸化滴定を行なうこ と。

注 2. $0.1 N$ 過マンガン酸カリウム消費量は, 初め に用いた過マンガン酸カリウム $\mathrm{cc}$ 数の1/5内外， すなわち, $25 \mathrm{cc}$ の場合には $3 \sim 7 \mathrm{cc}$ の範国で なければならない。

注 3. 使用する水怙よび硫酸溶液について, 上と全 く同じ条件でブランクテスト空行等う。

〔腐植酸の吸光度の测定]

酸化滴定を行なら前に腐植抽出液および腐植酸のフル カリ溶液の吸光度を測定する。

なお，吸光度の測定は波長 $600 \mathrm{~m} \mu$ および $400 \mathrm{~m} \mu$ 亿つ いて，口光板光度計定用いるときはそれぞれとれに相当 する適当なフィルターーを選択して行なう。

注 1. 應植酸のアルカリ溶液は 放置すればしだいに 退色するから，溶解後 2 時問以内に測定したほ うがよい。

注 2. 比色のさいのフルカリの濃度は $0.05 \sim 0.5 \%$ の範囲なら結果に影響しない。なお, 腐植酸溶 液では BEER の法則が成立する。

[実鉤結果の表示]
1) 沈殿部制合 $(\mathrm{PQ})$ : 抽出された腐植中の腐植酸部 の占める制合宗すをのであり，次式によって算出す る。

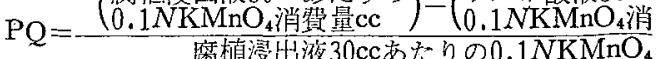

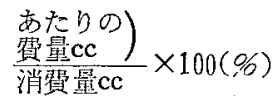

2）相対色度 (RF)：應植酸単位量あたりの色の謴さ を示す。

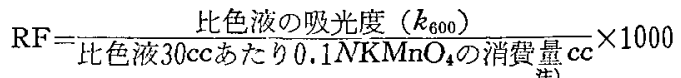

3）色調俰数 $(\triangle \log k): \triangle \log k=\log k_{400}^{\text {(i) }}-\log k_{600}$

注 1. $k_{400}$ 扎よび $k_{600}$ 法波長 $400,600 \mathrm{~m} \mu$ 亿おける 吸光度索対数目盛で測定し，この数値要再度 10 の対数值に換算し $\triangle \log k$ を求める)

\section{2 メトキシル基の定量}

小坂・本䄄が行なった方法で, ッォイゼル微量法の装 置をそのまま応用し VEIBöCK の容量法により定量し た。この装置はメトキシル基のみならず，エトキシル基

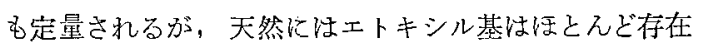

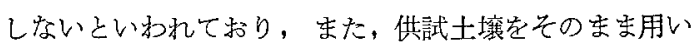
てもなんら メトキシル基の定量にさしつかえないことが 小坂・本田比より明らかにされているので， $0.5 \mathrm{~mm} の$ ふるい老通した試料をそのまま供試した。

操作法は 図1亿示すエトキシル基定量用のッフイゼル 微量法の装置を用い，まず，装置を発煙硝酸，水で洗い 乾燥器でかかかす。この場合，フルコールを使用すると 装置に残留する場合があり，值が大きくなるから避けな ければならない。

Eの内外学水で洗い, 毛細部Cに水滴定入れ, ゴムせ んをする。Wに $5 \%$ 硫酸カドミウムおよび5\%チオ硫酸

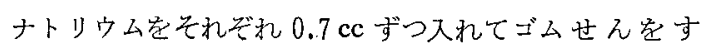

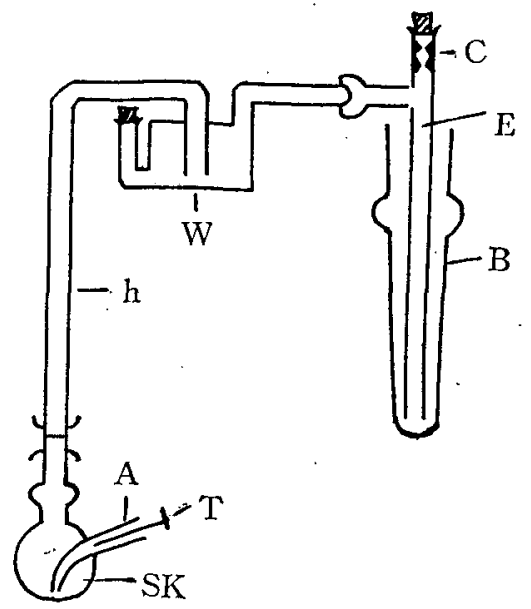

図1メトキシル基定量装置 
る。受器 $\mathrm{B}$ 定水洗して，10\%酰酸ナトリウム氷酰酸溶液 （酶酸ナトリウム $10 \mathrm{~g}$ 安水酶酸に溶解し氷酶酸にて $100 \mathrm{cc}$ とする） $4 \mathrm{cc}$ 和よび臭素 7〜8滴（真素浱度が希薄にな ったものは使用しないとと）を加党て導入管在をえつ し、 $\mathrm{E}$ の下端が $\mathrm{B}$ の底から $1 \sim 2 \mathrm{~mm}$ 離孔ているように 固定する。Bの管口法杀ギ酸で湿した脱脂綿でおおう。 SKフラスコにAからスズはくで包えな゙試料 $0.15 \sim 0.2 \mathrm{~g}$ を入れ（SKフラスコが取りはずしできる場合はそのまま 試料定 SKフラスコにはかり取ってもよい。この場合活 スズはくは不用)さら゙にフェノール少量, 無水酰酸 10 滴, 最後に豆化水素酸 $5 \mathrm{cc}$ を入れる。Akガラス棒 $\mathrm{T}$ をそう入し，キップの装置から炭酸がス它ゴム管を通じ て送り，B内安上昇严るきほが同時に2 個以下存在す るように調整する。SKの下部完ミクロバーナーで熱し 30分間煮沸する。 ヨウ化水素酸は h で還流するよう火加 減を調整する。受器内で真素渎留されてくるヨウ化 チルと次式のごとく反応する。

$$
\mathrm{CH}_{3} \mathrm{I}+\mathrm{Br}_{2} \longrightarrow \mathrm{CH}_{3} \mathrm{Br}+\mathrm{BrI}
$$

$$
\mathrm{BrI}+3 \mathrm{H}_{2} \mathrm{O}+2 \mathrm{Br} \longrightarrow \mathrm{HIO}_{3}+5 \mathrm{HBr}
$$

冷却後, 受器 B 它下げてその液面から $\mathrm{E}$ の下部定噰 し、CのゴムせえをはずしてEの内外定水でよく洗う。 一方において滴定用三角フラスコに20\%酷酸ナトリウム 液 $10 \mathrm{cc}$ を入れておき, Bの内容物をあけ, さらに3 回 少量の水で洗いこむ。 $2 \sim 3$ 滴のギ酸等にそって加 克,フラスコを振ってから，メチルレッドで臭素が存在 するか否かをたしかめる。值ちに脱色するときは酸堂 1 滴追加する。メチルレッドで微紅色を呈していれば臭 素は存在しないから，10\%ヨウ化カリウム $5 \mathrm{cc}$ 家ピペッ トで加光, $2 N$ 硫酸 $10 \mathrm{cc}$ を加えた後, 共せん定して2 分間放置する。1/100Nチ才硫酸ナトリウムで滴定し，淡 黄色之なったら，デンプン液を入れて淡紅色（メチルレ ッドの色）になるまで滴定する。

$$
\begin{aligned}
& 1 / 100 N \text { チオ硫酸ナトリウム } 1 \mathrm{cc}=0.02 \mathrm{mg} \\
& \text { メトキシル基態炭菜 }
\end{aligned}
$$

注 1. 現在市販されているッォイゼル微量法の装置 を使用する場合溶量が小さいため用いる試葙 の量を $1 / 2$ にする。

注 2. 三丨化水素酸はフンプルをあけてから長く保 存できないので $25 \mathrm{~g}$ 入りをそるえるとよい。着 色してもすかして子党るくらいなら使用でき る。

注 3. 本装置用いて $\mathrm{A} \cdot \mathrm{O} \cdot \mathrm{A} \cdot \mathrm{C}$ 法によって浿定 してもよい。

\section{3 應植酸の精製}

各試料の腐植酸は炭菜含量の約 300 倍になるよう, 0.5 \%水酸化ナトリウムを加えて, 沸騰湯浴中にて30分間加 温浸出し, 冷後, $10,000 \mathrm{rpm}, 10$ 分間遠心分離し, 浸出 液を得る。浸出液 $100 \mathrm{cc}$ に対し $1 \mathrm{cc}$ の割合で浱硫酸を加
え, 履植酸它沈殿させる。乙れ袁心分離, 水洗を繰り 返光し，腐植酸它得る。この腐植酸号 $0.5 \%$ 水酸化ナ卜 リウムに溶解させる。熊田による腐植酸の吸光曲線を測 定する場合怡これ学そのま試料とする。

示差吸光曲線を測定する場合は，できるだけ無機成分 它除去しなければならない。精製法你種々あるが，本研

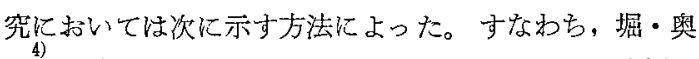
曰の方法にしたがって $0.5 \%$ 水酸化ナトリウムに溶解し た腐檩酸をイオン交換樹脂 OH 型 IRA 400 (80cc) の力 ラム最初纪通過させ，次に同じくH型 IR $120(80 \mathrm{cc})$ のカラムを通過させる。沈殿するものがあ机ばこ來究遠 心分離主る。この上うにして水溶性精製腐植酸它得た。

\section{4 示差吸光曲線の湘定}

腐植酸の示差吸光曲線の測定は, GOLDSCHMID 法に 準じたが、弘法・藤沢が行なったように綏衝液の $\mathrm{pH}$ 6 と10Kした。すなわち, 水溶性精製腐植酸を次に示す 2 種の緩衙液により $50 \mathrm{cc}$ に希釈する。この溶液の濃度 は 200〜700 maの間で示差吸光度が最高0.3〜0.6になる のがよい。

綏衙液 (1) ( $\mathrm{pH} 10$ の緩衝液)

$0.2 N$ の水酸化ナトリウム溶液 $43.9 \mathrm{cc}$ と小ウ酸括よび 塩化カリウムの浱度がそれぞれ $0.2 M$ Kなるように調製 した溶湤 $50 \mathrm{cc}$ と老混合し, 弥留水で希釈する。

緩衝液 (2)（pH 6 方綏衝液）

$0.2 N$ のリン酸二水素カリウム溶液 $495 \mathrm{cc}$ と $0.1 \mathrm{~N}$ の 水酸化ナトリウム溶液 $113 \mathrm{cc}$,と混合し, 蒸留水で $2 l$ に希釈する。

緩衝液(2)に溶解した腐植酸を対照として 緩衝液(1)に溶 解した腐植酸の吸光度安測定する。すなるち，波長200〜 $400 \mathrm{~m} / \mathrm{x}$ にいては $5 \mathrm{~m} \mu$ 間隔, 400 500 $\mathrm{m} \mu$ 亿おいては $10 \mathrm{~m} \mu$ 間隔，また， $500 \sim 700 \mathrm{~m} / 2$ に括いては $50 \mathrm{~m} /$ 間隔 に測定卞る。

このようにして得た各波長点における示差吸光度を $1 l$ 中に腐植酸の炭素 $1 \mathrm{~g}$ を含む溶液の示す吸光度に換 算して, 横軸に波長, 紸軸に示差吸光度 $(\Delta K)$ をとり 示差吸光曲線を図示した。なお, 測定液の腐稙酸の炭素 濃度は過マンガン酸カリウム消費量によって求めた。

\section{5 腐植酸の吸光曲線の測定}

$0.5 \%$ 水酸化ナトリウムに溶解した腐植酸を $700 \mathrm{mak}$ おける吸光度が 0.05 0.1 になるように腐植酸の湛度を 調整し，\&た，水酸化ナトリウムの浱度は 0.05 0.5\% の範囲比して, 示差吸光度の測定を行なった場合と同様

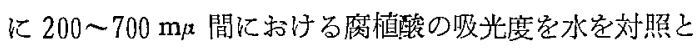
して測定する。

測定值は片対数グラフを用い, 横軸に波長, 縱軸に吸 光度 (対数目盛) をとり吸光曲線安図示した。使用した 分光光度計注津製 $\mathrm{QB}-50$ 型である。 
表 2 供 試土鎜 $の$ 分類

\begin{tabular}{|c|c|c|c|c|c|c|c|}
\hline 土 壌 & 採 & 取 & 名 & 層 位 & 母 & 材 & 備 \\
\hline 牧之原 1 & \multicolumn{3}{|c|}{ 静岡県榛原郡楱原町静谷 } & I & \multicolumn{2}{|c|}{ 非固結水成岩 } & 赤黄色士 \\
\hline 牧之原 2 & & \multicolumn{2}{|c|}{ 小篮郡菊川町會沢 ． } & I & \multicolumn{2}{|c|}{ " } & 中間 型 \\
\hline 牧之原 $3-1$ & $"$ & \multicolumn{2}{|c|}{ 嫀原邲榛原町六本松 } & I & \multicolumn{2}{|r|}{$"$} & 「黑ボク」I層 \\
\hline 牧之原 $3-2$ & $"$ & \multicolumn{2}{|c|}{ " } & II & \multicolumn{2}{|r|}{.} & " II尿 \\
\hline 三 重 & 三重 & 具山市笔日 & 重目茶羍分場 & $\mathrm{I}$ & \multirow{2}{*}{\multicolumn{2}{|c|}{ " }} & 赤薮色 士 \\
\hline 京 & 宇治 & 府立茶業砛 & & I & & & " \\
\hline \pm & 吉原 & 于石坂静岡皆 & 試富士分場 & I & & 山 & 火山灰士 \\
\hline 㥓 & 枕崎 & 別府茶試 & 支場 & I & & $" 1$ & " \\
\hline 埼 & 埼玉 & 入間郡武莀 & 扇町屋 & I & & $"$ & $"$ \\
\hline
\end{tabular}

\section{3 実験結果および考察}

\section{1 供試土淁の分類}

本研究に供試した土壤を類別すると表 2 に示すと招り である。

牧之原台地土壇は畑土堙生産力試験により分類された ものに従った。牧之原 2 の中間型というのは腐植質士瓖 （黑ボク）乙赤黄色士の中間に位すると思われる土壤 で，表層腐植層という点で両土壤と区別されたものであ る。

また，牧之原台地を含め東海地方分布する多腐植質 土㙵（黑ボク）は火山灰土塨と一般的性質はよく類似乙 ているが, 典型的火山灰土塨とは異なり，フロフェンな どの非晶質鉱物を主体とせず，主要粘土鉱物組成は三八 面体 $\mathrm{Al}$ バーミキニライト，分ロイサイト，ギブサイト を主としていることが, 加藤により明らかにされている ので, 表 2 備考に示したごとく，牧之原 3-1，2の土

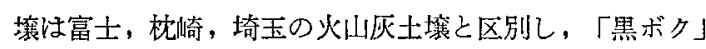

と呼称し，考察军行なうことにした。

以上の理由により，表括よび図の土壊名は採取地点名 で示すが，考察に当たって注赫黄色士，「黑ボク」およ び火山灰土として区別し，牧之原台地土境については赤 黄色土, 中間型㧍よび「黑ボク」として区別し考察を行 なった。

\section{2 SIMON の修正法（弘法・大羽）による 㢈植の形態}

供試土䇎の腐植の形態を SIMON の修正法により調べ た結果は表 3 に示すごとくである。

すなわち，PQ 值は赤黄色士に属するものは火山灰土 および「黒ボク」に比して小さく，また，赤黄色士の腐 植浸出渡扎よび腐植酸溶液の $R f$ 值は「黒ボク」および 火山灰土のものより小さく,乙れとともに $\triangle \log k$ 汢大 きな数值完しているので, 赤黄色士の腐植梳「黒ボク」 および火山灰土のものより腐植化が進えでいないことが わかる。

表 3 供試士袞の弘法・大羽による SIMON $の$ 修正法による腐植の形態 $(0.5 \% \mathrm{NaOH}$ 可溶)

\begin{tabular}{|c|c|c|c|c|c|c|c|c|c|c|c|}
\hline \multirow{3}{*}{ 土 猿 名 } & \multirow{2}{*}{\multicolumn{2}{|c|}{$\begin{array}{l}30 \mathrm{cc} \text { 当たり } 0.1 \mathrm{~N}- \\
\mathrm{KMnO}_{4} \text { 消費量 }\end{array}$}} & \multirow{3}{*}{$P Q$} & \multirow{3}{*}{$\begin{array}{l}\text { 腐 植 } \\
\mid \text { 此色液 } 30 \\
\mathrm{cc} \text { 当たり } \\
0.1 \mathrm{~N} \\
\mathrm{KMnO}_{4} \\
\text { 消費量 }\end{array}$} & \multirow{3}{*}{$k_{600}$} & \multirow{3}{*}{$R f$} & 夜 & \multicolumn{4}{|c|}{ 腐 植 酸 溶 液 } \\
\hline & & & & & & & & $\mid \begin{array}{l}\text { 皆色液30 } \\
\text { cc当たり }\end{array}$ & & & \\
\hline & 浸出液 & フルボ酸 & & & & & & $\begin{array}{l}\mathrm{KMnO}_{4} \\
\text { 消政量 }\end{array}$ & & & \\
\hline 牧之原 1 & $76.3^{\mathrm{cc}}$ & $\begin{array}{r}\mathrm{cc} \\
31.8\end{array}$ & $58.3^{\%}$ & 6.10 & 0.102 & 16.7 & 0.635 & $11.30^{\mathrm{cc}}$ & 0.275 & 24.3 & 0.515 \\
\hline 牧之原 2 & 100.0 & 39.4 & 60.6 & 4.00 & 0.110 & 27.5 & 0.549 & 5.60 & 0.330 & 58.9 & 0.455 \\
\hline 牧之原 3-1 & 76.3 & 34.3 & 54.9 & 3.05 & 0.285 & 93.4 & 0.437 & 3.80 & 0.330 & 86.8 & 0.412 \\
\hline 牧之原 3-2 & 141.1 & 10.8 & 92.3 & 2.82 & 0.410 & 145.3 & 0.365 & 3.29 & 0.480 & 145.9 & 0.360 \\
\hline 三＼cjkstart重 & 15.3 & 2.6 & 83.0 & 15.33 & 0.195 & 12.7 & 0.688 & 0.68 & 0.030 & 44.1 & 0.477 \\
\hline 京 & 10.8 & 4.5 & 49.0 & 10.77 & 0.335 & 31.1 & 0.692 & 0.99 & 0.102 & 103.0 & 0.471 \\
\hline 富 & 111.0 & 17.0 & 84.6 & 2.22 & 0.210 & 94.5 & 0.394 & 2.14 & 0.265 & 123.8 & 0.376 \\
\hline 视 & 126.0 & 6.5 & 94.8 & 2.52 & 0.251 & 99.6 & 0.364 & 2.25 & 0.305 & 135.6 & 0.358 \\
\hline 埼 & 87.0 & 15.2 & 82.5 & 1.74 & 0.230 & 132.1 & 0.371 & 2.25 & 0.275 & 122.2 & 0.367 \\
\hline
\end{tabular}

\section{3 供試土壤およひ腐植類似物質の} メトキシル基含量

小坂は腐植の骨格をリグニンとし，本邦高位地土培の
メトキシル基含量を調へ，それによって腐植化過程を 5 段階に大別した。供試土境すよび腐植類似物質のメトキ ‘シル基含量を示すと表 4 のとおりである。 
表 4 供試土塨および腐植類似物翼の

メトキシル基含量

\begin{tabular}{|c|c|c|c|}
\hline 土壤名 & 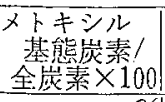 & 腐植類似物質 & 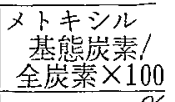 \\
\hline 牧之原 1 & $1.380^{\circ}$ & 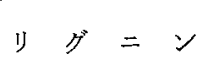 & $5.210^{\circ}$ \\
\hline 牧之原 2 & 0.976 & テンポロン & 2.080 \\
\hline 牧之原 3-1 & 0.688 & ニトロフミン酸 & 0.660 \\
\hline 牧之原 3-2 & 0.200 & & \\
\hline 三 重 & 1.070 & & \\
\hline 京 都 & 1.117 & & \\
\hline 富 士 & 0.403 & & \\
\hline 枕 崎 & 0.413 & & \\
\hline 埼 玉 & 0.378 & & . \\
\hline
\end{tabular}

これによると，赤黄色土に属する土境にあっては，1 \%以上を示し，小坆によるB段階のものといえる。牧之 原「黒ボク」I㒶はメトキシル基含量が比較的多く、C 段階を示している。これは每年敷草が施用されているた めと思われる。 $R f$ 値淤最も大きい牧之原「黑ボク」П層 はメトキシル基合量がきわめて少なく， $\mathrm{E}$ 段階に近づい ていること宗している。火山灰士のメトキシル基含量 は 0.4 \%前後で D段階に属するものといえる。

腐植類似物質としてりグニンおよび市販されているフ ミン酸系土壤改良戍以ついて調べてみると，リグニンは メトキシル基含量が $5.21 \% て ゙$ テンポロンは 296 定示し 土壤腐植酸よりかなり未熟なととを示し，ニトロフミン 酸のメトキシル基含量は火山灰土および「黑ボク」腐植 酸のそれに近い含量を示していた。

小坂によれば，赤黄色土に含まれる腐植酸以酸可溶性 窒素含量が多く良質なすのであるが，これら土筷の風化 ，過程においては生成する活性アルミニウムが少なく，成 '植と結合するのに十分でなく，不安定であり，てれに加 えてわが国のような湿潤，湟暖な気俟に支配されればす みやかに分解され，火山灰土および「黒ボク」などのよ うに腐植が集積しないのであるうと推察している。

\section{4 腐植酸およひ腐植類似物質の示差吸光曲線}

まず，リグニン，テンポロンおよびニトロフミン酸の 示差吸光曲線を示すと図2のと扔りである。

リダニンの示差吸光曲線は弘法・藤沢のむのと注やや 異なるが, $250 \mathrm{~m} \mu, 350 \mathrm{~m} \mu$ 付近にめいりょうな吸收極大

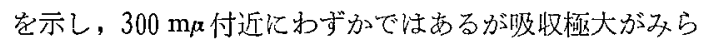
れる。

GOLDSCHMID によれば 250 および $300 \mathrm{~m} \mu$ 付近の吸収 極大はフェノール性水酸基の存在および多少を示し, 芳 香核定通してカルボニルグループと水酸基グループとが 共役的に結合しているようなフェノール性化合物のアル カリ性溶液は 250,350 お よび $400 \mathrm{~m} / \mathrm{s}$ 付近飞吸収極大を 有するといるれている。したがって，300 $\mathrm{m} /$ 付近の吸収

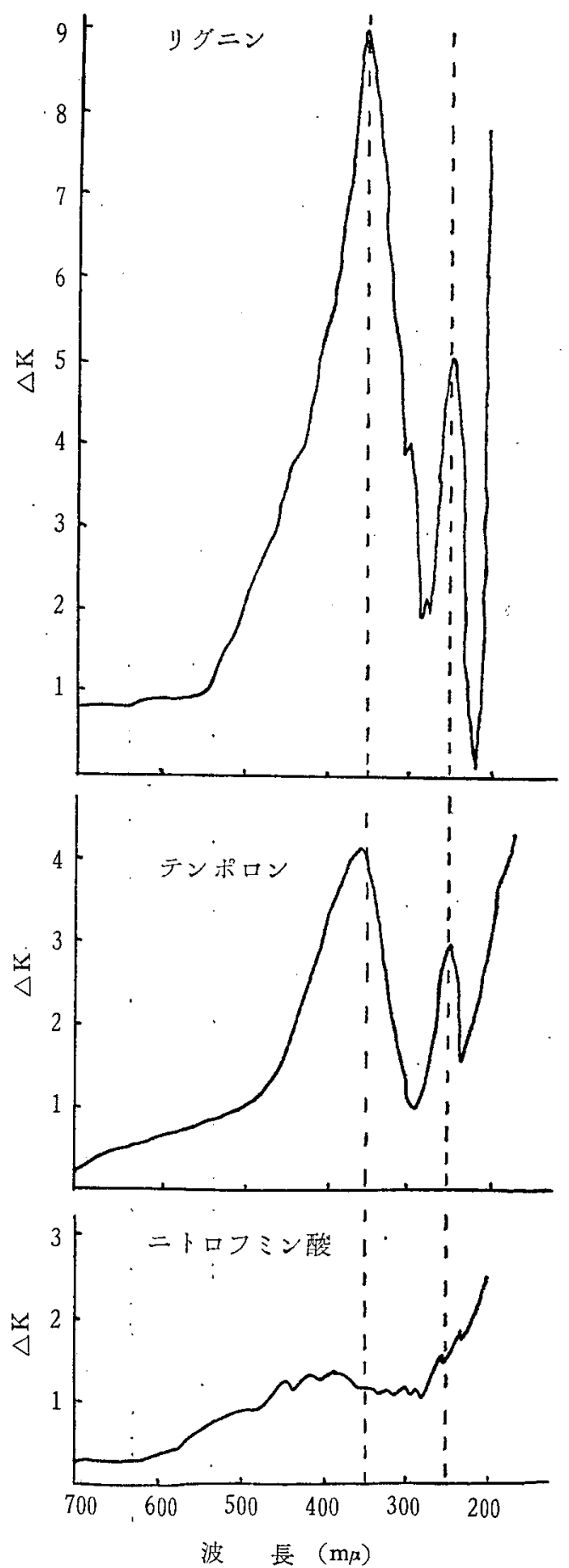

図2 腐植類似物質の示差吸光曲線

極大は共役していないフェノール性水酸基の特有な反応 であるといえる。

テンポロンは泥炭に石灰を加克，加压，加熱処理をし たものであるので，リグニン的性買がめいりょうに認め られており，250および $350 \mathrm{~m} /$ によらる吸取極大の数 
值 $(\triangle K)^{*}$ がリグニンに比較してメトキシル基含量の差 異とほとえど比例的に小さくなっている。ニトロフミン 酸についてみると，ほとんどリグニンにみられるフェ， 一ル性水酸基グループの反応が多られず，極度に酸化さ れていることが認められる。

牧之原台地の赤黄色士，中閐型和よび「黑ボク」の鹰 植酸の示差吸光曲線についてみると図 3 のどおりであ 当。

赤黄色土の應植酸注リグニン的性質がめいりょう䍀 められ，350 m爪に和ける $\triangle K$ およびメトキシル基含量 はテンポロンの約 $1 / 2$ にっている。中間型土塨の腐植酸 はメトキシル基合量が赤黄色土より少なくなるとともに リグニン的性質が薄らいでくる。「黒ボク」腐植酸にあ っては，注とえどリグニン的性質が認められない。これ ら 3 種の腐植酸には $300 \mathrm{~m} /$ 付近にわずかではあるが， 吸收極大が認められ，非共役のフェノール性水酸基の存

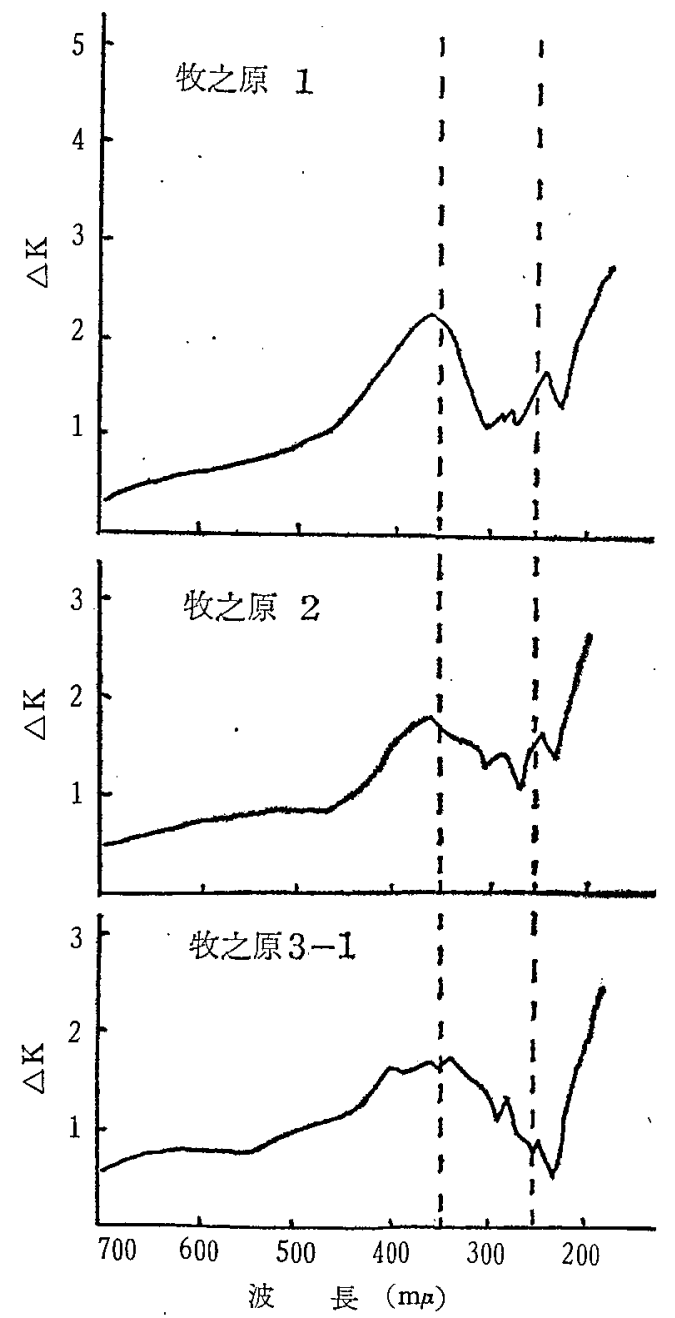

図 3 牧之原台地茶園土㩙腐植酸の示差吸光曲線
在妿認的られる。なお,これら 3 土境の生産性は中間型 そ赤黄色士>「黑ボク」の順である。

FLAIGが斐和らの土塨中に扮ける分解過程它調べた結 果に上れば，分解が進み， 410 日後には简植に含まれる空

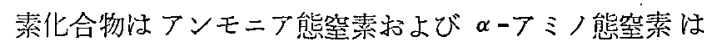
減少し始め， へテロサイクリックの等素化合物が增加す ることが諗められている。これらは小坂によっても酸可 溶性空素の增減について考察されたとおりである。ま た，弘法・藤沢らは，てれらの性質を舆にする腐植酸と 粘土との反応について調べた結果, リグニン的性犋の強 い，すなるち，フェノール性水酸基の多いもの汪ど粘土 とよく結合することを誌めている。

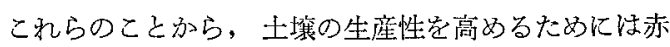
黄色士に含まれている腐植化段階のもの，すなわち，小 坂によるB段階のものをより多く集積させることである と考党られる。また，小坂の指摘したごとく，チェル， 一ゼムの腐植はB段階のものである。

次に赤黄色土，「黒ボタ」および火山灰土袞の腐植酸 の示差吸光曲線を比較してみると図 $4 ， 5$ および6に示 すと抢りである。

、寸なるら，赤黄色土に属する土銮の腐植酸はいずれる リグニン的性質が認められ，「黒ボク」および火山灰土 の腐植酸に法認めら肘い。埼玉の土壤は，火山灰土と

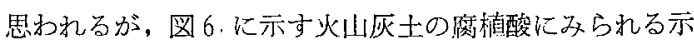
差吸光曲線と異なり,むしる「黑ボク」の腐植酸に近い 性質を示すので，今後の土㙵調查および本質的性質の解 明により明らがしたい。

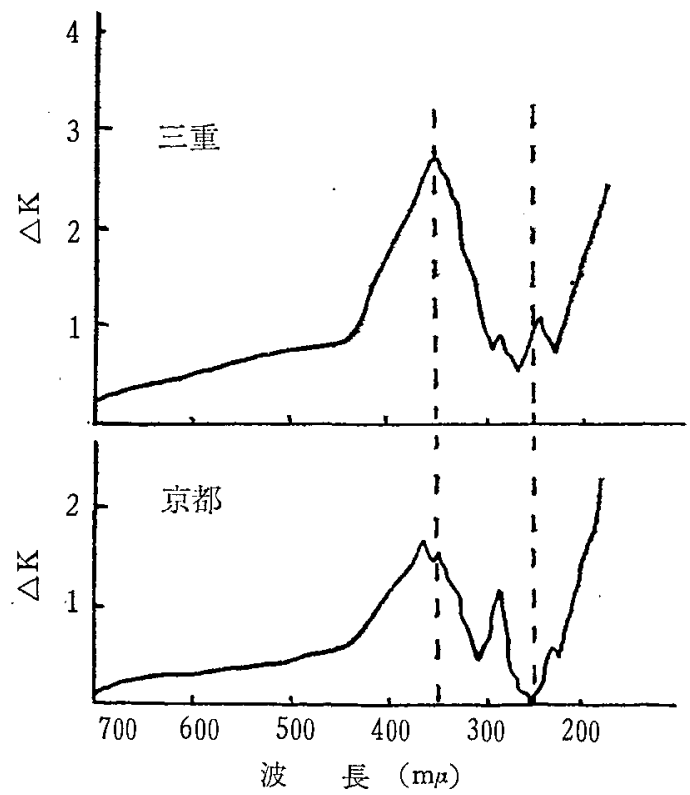

図 4 赤黄色土腐植酸の示差吸光曲線

* 示差吸光度を $1 l$ 中炭素 $1 \mathrm{~g}$ を含有する溶液の場合に換算。 


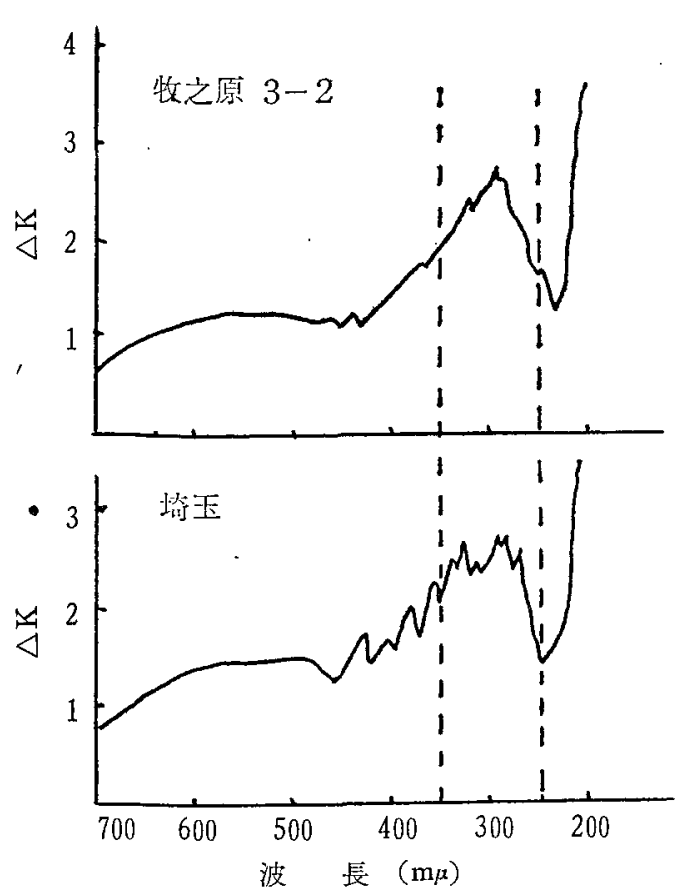

図 5.「黑ボク」および埼玉土㵝腐植酸の示差吸光曲線

「黒ボク」括よび火山灰土の腐植酸は 熊田の赤外線吸 収スペクトルの測定により赤黄色土の腐植酸などよりフ ェノール性水酸基は少なく，カルボキシル基の多いこと が認められ，小坂によっても定量的に調べらて秃ている。 また, FLAIG も麦わらの腐植化過程において同栐な傾向 を認めている。

メトキシル基含量あるいは，熊田の吸光曲線による䧹 植の形態分別法が土壇分類に役立っているが，「黒ボク」 と火山灰土に含まれる腐植酸についてはいまだ図 5 拉よ び6にみられるごとき，めいりょうな差異を認めること ができなかった。すなわち、示㚇吸光曲線を求めたなか から代表的な 4 種の土袞腐植酸について熊田による腐植 酸の吸光曲線空測定した。その結果は図 7 に示すごとく である。

しかし，図 5，6亿みられる性質の差異がなにに原因 するのか本実験の範囲において法明らかでない。

本研究結果が普遍的なものとは雅定できないが，これ が土塨分類化も役立てられるよう，今後あらゅる角度か ら追求する予定である。

\section{4 要 約}

赤黄色土，「黒ボク」および火山灰土に由来する茶園 土塨ならびに腐植類似物質のメトキシル基含量と腐植酸 の示差吸光曲線について調へた。年の結果を要約与当と 次のごとくである。

1）腐植化度が大きくなるにしたがってメトキシル基 含量が減少した。

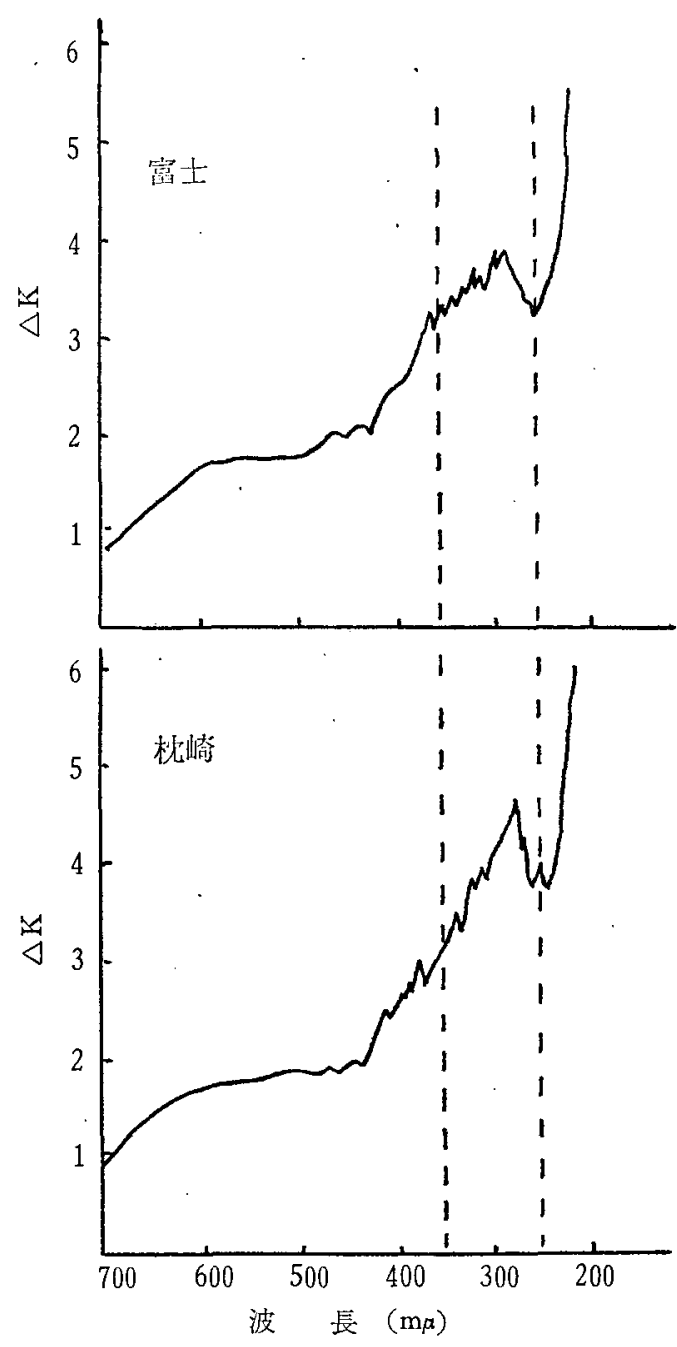

図6 火山灰土腐植酸の示差吸光曲線

2）赤黄色土，「黒ボク」沶よび火山灰士のメトキシ

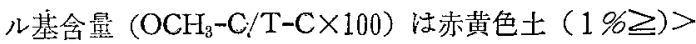
「黒ボク」=火山存士（0.2 0.6\%）の順であった。赤黄 色士の腐植酸活示差吸光曲線にリグニン的性 質を示主 が，「黑ボク」捛よび火山灰土の噟植酸はリグニン的性 質定示さず，芳香核を通してカルボニル基と共役二重結 合したフェノ゙ール性水酸基の反忘が認められなかった。

3）「黑ボク」腐植酸の示差吸光曲線汪火山厉土腐植酸 の示差吸光曲線とは明らかに形状が異なっていた。

4）リグニシ，テンポロンおよ゙びニトロフミン酸のメ トキシル基舍量はりグニン $(5.21 \%)>$ フンポロン $(2.08$ \%)>ニトロフミン酸 $(0.66 \%)$ の順であった。

テンポロンは示差吸光曲線にりグニン的性翼を強く示 し、ニトロフミン酸壮全くその性質を示さ等かった。

終かりにのぞみ，メトキシル基の定量技よび本研究に

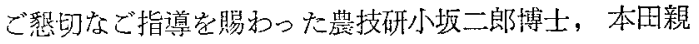
安技官，で配虑を賜わった加藤博場唇に深く感謝主る。 


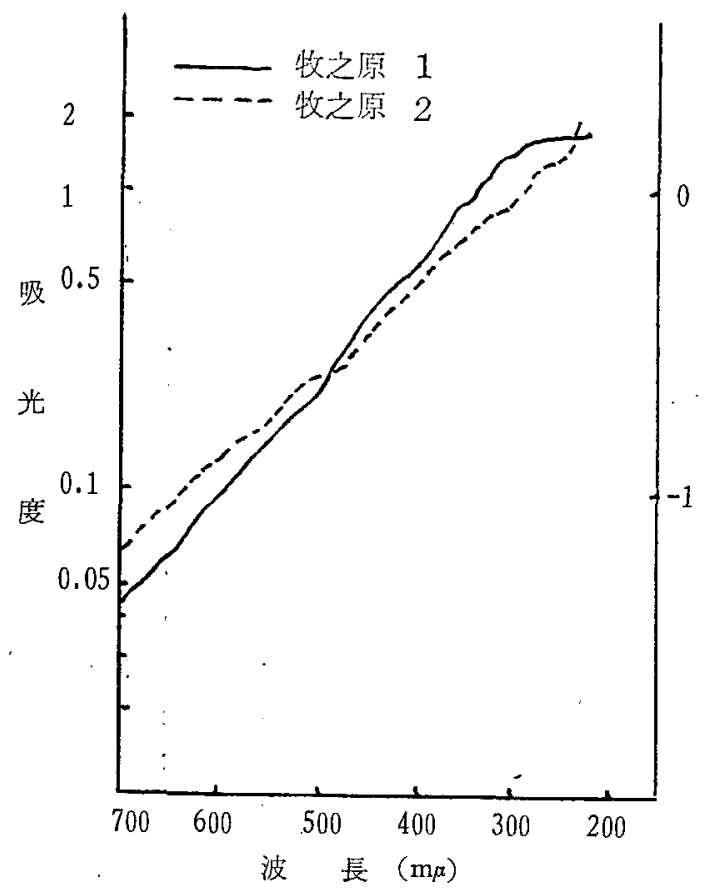

図 7

\section{5 文献}

1）河合牢吾, 池ヶ谷賢次郎：茶技協檴要，p.6 (Nov., 1962).

2）小坂二郎，本田親史：土肥誌，27，435 438 (1957).

3) Kumada, K. : Soil and Plant Food, 1, 29 30 (1955).

4) HORI, S. and A. OKUdA : Soil Science and Plant Nutrition, 7, 4(1961).

5) Goldschmid, O. : Anal. Chem., 26, 1421 1423 (1954).

6）弘法健三, 藤沢 徹：土肥誌，33，97 100 (1962).

7）農林省農林水産技術会議事務局, 共同研究: 烟土 壤生産力に関当当研究, 189 204 (1962).

8）加藤芳朗：土肥誌，30，549 552（1960）.

9）加藤芳朗：土肥誌，32，328３32 (1961).

10）加藤芳朗：土肥䞏， 33，513 516 (1962).

11）加藤䓅朗：土肥誌， 33，517 520 (1962).

12）小坂二郎：農技研報告 $\mathrm{B}$, No. $13,253 \sim 352$ (1963).

13) Flaig, W: : Proc. Intern. Congr. Biochem., 4th. Congr., Vinner, 2, 227 244 (1958).

14）弘法健三，藤沢 徹：土肥誌，34，13１7

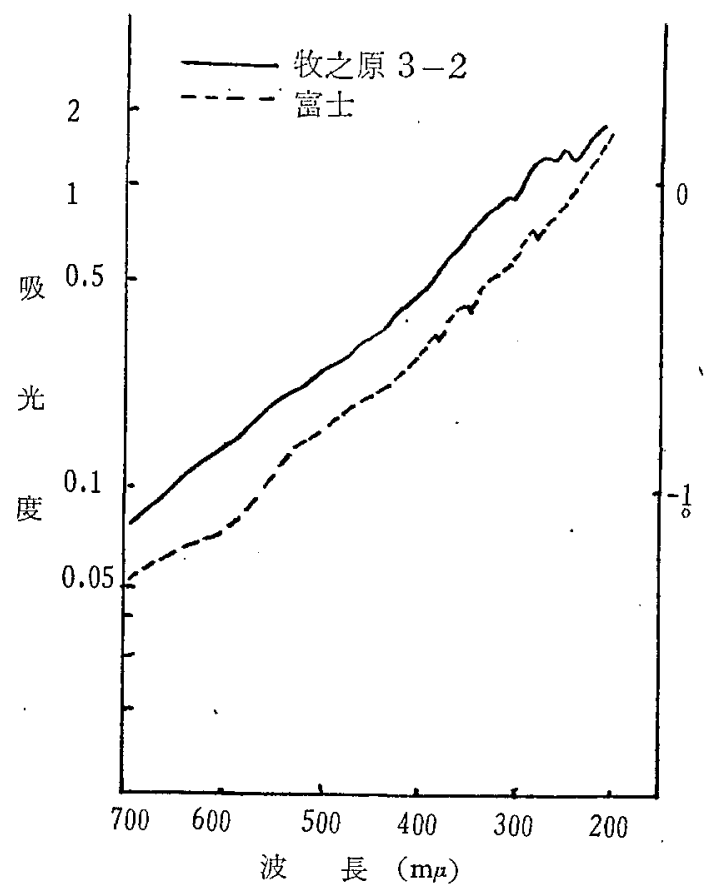

(1963).

15) Kumada, K. and K. Aizawa. : Soil and Plant Food, 3, 152 159 (1958).

\section{Summary}

The methoxyl content and difference spectra were examined of the tea soils derived from Red-yellowish soil, "Kuroboku" and volcanic ash soil and huminlike material.

The results were summarized as follows :

1) Methoxyl content decreased with increasing humification degree of these soils.

2) The order of methoxyl content $\left(\mathrm{OCH}_{3}-\right.$ $\mathrm{C} / \mathrm{T}-\mathrm{C} \times 100$ ) of these soils was as follows : Red-yellowish soil $(1 \% \supseteqq)>$ "Kuroboku" = volcanic ash soil $(0.2 \% \sim 0.6 \%)$.

The difference spectrum of humic acid in Red-yellowish soil indicated ligninlike pattern but those of "Kuroboku" and volcanic ash soil did not indicate such pattern.

In the difference spectrum, the absorption band of phenolic hydroxyl group which is conjugated through the benzene ring with a carbonyl group was not observed on humic acid of "Kuro- 
boku" and volcanic ash soil.

3) The difference spectrum of humic acid was distinctly different between "Kuroboku" and volcanic ash soil.

4) The order of the methoxyl content of lignin, "Temporon" (soil conditioner of peat) and "Nitro humic acid" (soil conditioner : lignite was treated with nitric acid) was as fo- llows : lignin (5.21\%)> "Temporon" (2.08\%) $>$ "Nitro humic acid" $(0.66 \%)$.

The difference spectrum of "Temporon" humic acid clearly indicated a ligninlike pattern but that of "Nitro humic acid" showed a completely different pattern.

(Feb., 1,1964$)$

\title{
茶園土壌の特性について (第8 報) ${ }^{*}$
}

\author{
窒素に関する諸性質
}

農林省茶業試験場 河 合 惣吾

\section{The Characteristics of Tea Soils (Part 8).}

\author{
On the Nitrogenous Characteristics of Tea Soils
}

\section{By Sôgo KAWAI}

\begin{abstract}
1 まえがき
これまで，主として茶園土塎の特性として，その一般 理化学的性質を未耧地土塞および普通烟土㗧と対比して 研究を進めてきたが, 今回はさらに, 茶の生産に対して

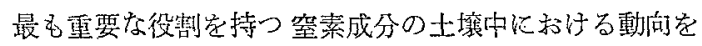
明らか炕するために，無機態空素（フンモニア態窒素， 硝酸態壁素）の層位別分布, 乾土効果, フンモニアの吸 収, アンモニア化成量および硝酸化成量などについて調 べたので報告する。
\end{abstract}

\section{2 供試土境およひ実験方法}

供試土壤は火山灰に由来する富士土境, 洪積層の赤黄 色土および黑ボクに由来する牧之原土境, 第三紀層の頁

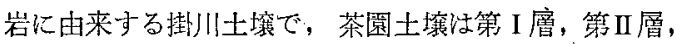
第正層，未耕地士境ならびに普通烟土境は第 I 層を供試 した。これら供圾土鋉の一般化学的性質を示すと表 10 と和りである。

また，実験方法の概要宗すと次のごとくである。 無機態耋素（フンモニア態啨素，硝酸態窒素）の層位 別分布：土境に10\%塩化カリウム溶液を加兄，振とう浸 出し，浸出液に酸化マグネシウムを加え蒸留してアンモ
ニフ態窒素を定量した。硝酸態窒素の定量はフォノール ジスルホン酸法によった。

乾土効果: 風乾土儿水加六て, 水分を最大容水量の $60 \%$ とし $30^{\circ} \mathrm{C}$ に2 週間保った後, アンモ二フ態空素お よび硝酸態空素定量し，これらの值から処理前のそれ ぞれの値学差し引いて乾土効果とした。また，フンモ二 フ態窒素と硝酸態窒素の生成量の合量を各全墪素量で割 り 100 倍して化成率とした。

アンモニフ吸収： $\mathrm{pH} 7$ に調節した $0.1 M$ のリン酸フ ンモニウム, 炭酸アンモニウム, 硫酸アンモニウムおよ び塭化アンモニウム溶液空つくり，これらの溶液 $50 \mathrm{~m} l$ を風乾土 $25 \mathrm{~g}$ 亿加光，1時間振とうし24陵間室温に静置 後口過， 口液の一定量をとってアンモ二フ態空素定定量 した。そして添加量から口液中の量を差し引いて四収量 とし，添加量に刘する吸收量の比学吸収率とした。

アンモニフ化成量：風乾土 $100 \mathrm{~g}$ に，Nとして $56.5 \mathrm{mg}$ 相当量の宗素を加え，さらに炭酸石灰 $1 \mathrm{~g}$ を加えた区を つくり, 烟地状態（容水量の60\%の水分）として $30^{\circ} \mathrm{C}$ に2，4，7 日放置後，それぞれアンモ二フ態窒素を定 量した。そしてこれらの值から窒素無添加区の值を差し 引いて化成量とした。

硝酸化成量 : 風乾土 $100 \mathrm{~g}$ に $\mathrm{N}$ とて $53 \mathrm{mg}$ 相当量の

* 茶業技術研究 No. 29，47～55（1964）より転載 